The Road Home: Rebellion, the Market and Masculinity in the Han Han Phenomenon

\title{
Pamela Hunt
}

\section{OpenEdition}

\section{Journals}

Electronic version

URL: https://journals.openedition.org/chinaperspectives/10372

DOI: 10.4000/chinaperspectives. 10372

ISSN: 1996-4617

\section{Publisher}

Centre d'étude français sur la Chine contemporaine

Printed version

Date of publication: 1 September 2020

Number of pages: 29-37

ISSN: 2070-3449

\section{Electronic reference}

Pamela Hunt, "The Road Home: Rebellion, the Market and Masculinity in the Han Han Phenomenon", China Perspectives [Online], 2020-3 | 2020, Online since 01 September 2021, connection on 10 December 2021. URL: http://journals.openedition.org/chinaperspectives/10372 ; DOI: https://doi.org/ 10.4000/chinaperspectives.10372 


\title{
The Road Home: Rebellion, the Market and Masculinity in the Han
} Han Phenomenon

\author{
PAMELA HUNT
}

\begin{abstract}
Han Han has attracted a significant amount of popular and scholarly attention since he rose to fame in 1999. While the majority of commentators have concentrated on his ambiguous position as rebel-meets-entrepreneur, this article considers the way in which masculinity is performed and constructed in the Han Han phenomenon. It discusses Han Han's commercial appearances before turning to his debut film The Continent (2014). The article points to the recurring figure of the adventurous mobile man, demonstrating that this celebration of masculinity on the move is the result of global cultural influences, local traditions of manhood, and new market forces. Founded as it is on a conservative understanding of gender and mobility, Han Han's performance and construction of masculinity cuts into his reputation as a "deviant genius," demonstrating further ways in which his cultural rebellion is limited. In particular, this article highlights the ways in which his masculinity is constructed at the expense of women and non-hegemonic men.
\end{abstract}

KEYWORDS: Masculinity, mobility, Han Han, road movies, rebellion, celebrity, postsocialist cinema.

start with an image of the novelist, blogger, and filmmaker Han Han (韓寒, born 1982). Part of an advertising campaign for Nescafé coffee, it appears at the end of a two-minute film that was broadcast online in 2011. ${ }^{1}$ Han Han sits on a rocky outcrop, red desert and a bright blue sky behind. He is dressed in a leather jacket, blue jeans, and sturdy boots, with a gleaming motorbike parked beside him. He is looking directly at the camera with a somewhat defiant expression, a red cup of coffee in his hand. "Live out your boldness!" (Huochu ganxing! 活出敢性!) cries the slogan at the top.

This image encapsulates several narratives that run through cultural production in postsocialist China. They also run through the Han Han phenomenon (Han Han xianxiang 韓寒現象), the term used to describe the rapid rise to fame of this multi-hyphenate pop culture icon. In the first instance, in featuring this bestselling novelist and so-called "literary bad boy" $^{\prime 2}$ as a leather-clad biker, we are presented with the image of culture meeting market meeting counter-culture, a trope that commentators have repeatedly observed throughout post-reform China (Barmé 1999; Fumian 2009). We might think of this advertisement as a variant of Geremie Barmé's (1999) concept of packaged or bankable dissent, as the iconography of resistance - the bike, the leather jacket, the choice of the outspoken Han Han as figurehead - is packaged for consumption of both coffee and celebrity. ${ }^{3}$ It is also a depiction of transnational mobility: far-reaching economic and cultural flows appear not just in the sense of a multinational conglomerate reaching into the local market, but also in the way pieces of this picture - the clothes, the mode of transport, the landscape, and even the colour palette - seem to have travelled to China via the West, or specifically America's Southwest, land of the Easy Rider and Marlboro Man. ${ }^{4}$ Finally, this image might also be read in terms of a celebration of a certain kind of masculinity: bold, macho, adventurous, and mobile.
It is this image of the mobile man that I will focus on in this article. Why, one might ask, does this mode of "doing man" hold such an appeal? Masculinity has re-emerged as a topic of concern within contemporary China. In the era of market reform and opening up to the world, it is discussed, critiqued, and carefully reconstructed according to shifting and diversifying ideas about ideal manhood. Public debates about how Chinese men ought to behave - be that as modern Confucian gentlemen (Hird 2016, 2017), enlightened fathers (Li and Jankowiak 2016), or tough "wolf warriors" (Liu and Rofel 2018) - are held with mounting frequency, and cries of a "crisis" are often heard (Song 2010; Hird 2012). ${ }^{5}$ Meanwhile, a growing number of gender scholars have sought to make masculinity visible within China studies, highlighting the ways in which it intersects with, and sheds further light upon, major points of concern in the postsocialist era, including the shifting position of the intellectual vis-à-vis the state (Zhong 2000); the rise of consumerist values (Baranovitch 2003; Osburg 2013; Hird 2016); and China's interactions with the rest of the globe (Louie 2015; Hird and Song 2018). Studies such as these have highlighted the transnational influences on

1. “韓寒活出敢性雀巢咖啡廣告” (Han Han huochu ganxing Quechao kafei guanggao, Han Han lives out his boldness in a Nescafé coffee advertisement), Youku, 22 November 2011 https:// v.youku.com/v_show/id_XMzI0ODA4MDQ4.html (accessed 21 May 2019).

2. Simon Elegant, "Han Han: China's Literary Bad Boy," Time, 2 November 2009, http://content.time. com/time/magazine/article/0,9171,1931619,00.html, (accessed 21 May 2019).

3. Barmé coined the term "bankable dissent" to refer to the "street cred" and market value that dissident writers and artists accrue regardless of their level of artistic prowess. Here any outright proclamations of resistance against state or authority have been entirely bypassed.

4. I am grateful to Professor Rebecca Karl for pointing out the connection between this image and the Marlboro advertising campaigns.

5. The sense of a crisis is neither new nor reserved for Chinese masculinity but is regularly declared around the world (Louie 2015: 4-8). For a discussion of the problematic nature of the concept of a "masculinity in crisis" see Connell (2005: 85); Whitehead (2002). 
contemporary Chinese gender, which have created new and hybridized ideals of masculinity, alongside the continuing importance of longstanding local understandings of "real men" as constituting wen 文 or cultural attainment, and wu 武, or martial valour (Louie 2015, 2016; Hird and Song 2018).

The Nescafé image is all the more interesting because it is a variation on a theme: Han Han has repeatedly been framed as an icon of countercultural movement, never far from a vehicle and the open road. What is the attraction of this form of masculinity for Han Han and postsocialist Chinese cultural production? What connects mobility and men, and what are the implications of this connection? What are we to make of the visual echoes of Western rebellious men in scenes such as this? How does this mode of masculinity connect both a countercultural stance and a celebration of consumer culture?

This article will explore the way in which masculinity is presented within the Han Han phenomenon. It will do this first through a visual and textual analysis of a series of advertisements and media appearances featured in print and online, and his previous literary works, before turning to his 2014 debut film The Continent (Houhui wuqi 後會無期). While Han Han has attracted a significant level of academic attention, no scholar has considered in detail the way in which he represents and performs masculinity. I argue here that this is a major facet of his public persona and his works. I argue also that this masculinity is consistently interwoven with a road discourse in which, across various texts, moving down the open road is celebrated as a way of achieving freedom, rebellion, and self-discovery. The connected themes of movement and masculinity running through the Han Han phenomenon are enmeshed in and reflect upon such issues as the complex interplay between global and local in China, and the tangled, ambivalent responses to continuing marketisation. The trope of mobile masculinity, moreover, cuts into Han Han's rebellious reputation, as the recurring image of freewheeling outlaws rely on conservative gender ideals, with the result that women's voices are frequently silenced.

\section{The Han Han phenomenon}

To understand why Han Han is such a compelling figure to explore in terms of rebellion and mobility, it is necessary to consider his career and position in Chinese popular culture. The label of "phenomenon" refers to the weight of attention and controversy that he has garnered, but also to his sheer ubiquity across several different media and sporting platforms. Born in 1982, he first came to fame aged 17 upon winning a nationwide writing competition. Despite dropping out of high school, he proceeded to write eight wildly popular novels that made him one of China's highest paid writers (Strafella and Berg 2015: 353). His blog, launched in 2005, rapidly became the most read in China (ibid.), leading to the print publication of several essay collections.

Han Han became associated with frank and fluent writing, filled with word play, satirical humour, an eagerness to deflate pomposity (including his own), and a willingness to highlight the hypocrisies lurking within Chinese society, from phoney nationalism to pretentious writers and critics. ${ }^{6}$ His talent for pushing at political and cultural boundaries of acceptability is combined with a nonchalant, ironic attitude that Xu Zhiyuan captured well when he observed - somewhat critically - that "he never betrays any anxiety or confusion. He is so cool... (hen ku... 很酷... $)^{m 7}$

The sense of restlessness that fills much of Han Han's work is echoed in his own career, as he has leapt into a number of different roles, ranging from magazine editor to app designer and film director. ${ }^{8}$ However, the career move that perhaps most marks him out as distinctive came earlier, in the form of his turn to rally car racing in 2003, a field in which he has excelled. ${ }^{9}$ As Veg points out, Han Han's many different roles grant him financial independence, a major factor in his ability to speak out. Crucially, his racing career creates a source of income that, unlike private publishing, is entirely separate from the state control of culture and media (Veg 2019: 225).

Amidst all of this, and in contrast to his image as a man "outside of the system" (ibid.), Han Han has regularly appeared in national and international media, be it through magazine interviews or online paparazzi-style exposés. TIME magazine named him one of the 100 most influential people in 2010, while he has been nominated as "man of the year" by Yazhou Zhoukan 亞 洲周刊 and Southern Weekly 南方周末 (Veg 2019: 226), as well as CQ China in $2010{ }^{10} \mathrm{He}$ regularly features on the front cover and in photoshoots for men's magazines such as $G Q$ and Esquire China. ${ }^{11}$ While Han Han's association with the more highbrow publications has attracted more attention, his presence in lifestyle magazines such as these is no frivolous detail, as they remind us of his image as intellectual-meets-pinup and his close ties to pop culture and consumer society. Moreover, the explicit validation of him as an ideal man brings to the fore the gendered aspect of the Han Han phenomenon. ${ }^{12}$

In the postsocialist era, when state, artists, and consumers have had to negotiate between residual socialist institutions and a rapidly growing market economy, the cultural field is often discussed in terms of ideological uncertainty, ambivalence towards reform, and a blurring of formerly clear boundaries (Lu 2007: 204-10; Zhang 2008; Hockx 2015: 16). Han Han, who embraces marketisation and celebrity culture whilst simultaneously critiquing the effects of market reform, has been identified by several scholars as a prism through which we might consider the shifting ways that consumerism, culture, and dissent interact in this period (Fumian 2009; Yang 2013; Coderre 2014; Strafella and Berg 2015; Veg 2019). Many of these consider whether Han Han's rebellious reputation is tenable when he is also so closely implicated with the consumerism that has come with market reform. Some, such as Yang, Coderre, and Veg, argue that his commercial

6. For detailed analyses of the most provocative essays, see Fumian (2009), Hockx (2015: 94-107), Strafella and Berg (2015), and Veg (2019: 225-234).

7. Xu Zhiyuan 許知遠, “庸眾的勝利” (Yongzhong de shengli, The victory of the masses), http:// book.ifeng.com/culture/1/detail_2010_05/11/1504069_0.shtml (accessed $1^{\text {st }}$ November 2019). Cited in Veg (2019: 237).

8. See Hockx (2015: 101-05) for details of the literary magazine Party (Duchuangtuan 獨創團) and its demise. See Hockx (2015) and Wen and Bi (2015) for a discussion of the app ONE (yige 個) which was launched in 2012. In terms of film, besides The Continent, Duckweed earned over 1 billion RMB at the box office in 2017; Pegasus earned 1.78 billion RMB. Data from Zhongguo piaofang, http://www.cbooo.cn/ (accessed on 7 November 2019).

9. An account of Han Han's racing career is provided in Tim Struby, "China's Literary Bad Boy Is the Most Interesting Race-Car Driver in the World," New York Magazine, 13 December 2016, http:// nymag.com/speed/2016/12/han-han-is-the-most-interesting-race-car-driver-in-the-world.html (accessed $1^{\text {st }}$ November 2019).

10. “年度媒體人: 韓寒. 我們要去更深處” (Niandu meiti ren: Han Han. Women yao qu geng shenchu, Media man of the year: Han Han:We have to go deeper), GQ China, 7 September 2011, https://www.gq.com.cn/celebrity/news_134226c037500269-2.html (accessed on 1t November 2019).

11. Han Han featured on the cover of Esquire China in 2006, 2009, 2011, 2012, and 2014.

12. A thorough detailing of Han Han's physical appearance is a trope even in the loftier publications. See Osnos's paragraph-long description of Han Han's "soft cheekbones and glittering black eyes," David Pilling's reference to his "mop of hair," leather jacket and "boyish disarming grin," or lan Buruma's account of his "shaggy-haired looks...and cool sassiness." Evan Osnos, "The Han Dynasty," The New Yorker, 27 June 2011, https://www.newyorker.com/magazine/2011/07/04/thehan-dynasty (accessed 21 May 2019); Pilling, "Lunch with the FT: Han Han," Financial Times, 21 April 2012, https://www.ft.com/content/3be0e84e-8896-11e1-a727-00144feab49a (accessed on $1^{\text {st }}$ November 2019); lan Buruma, "Essays by Han Han, the Chinese Blogger and Media Superstar," The New York Times, 4 September 2016 https://www.nytimes.com/2016/09/04/ books/review/han-han-problem-with-me.html (accessed on $1^{\text {st }}$ November 2019). 
presence still allows for, and even provides greater support for, his role as public intellectual and critic. Others, such as Strafella and Berg, depict the Han Han phenomenon as mere "spectacular rebellion" (Strafella and Berg 2015: 364).

The majority of these studies have focused on his essays and the provocative political positions that they have taken over the past 20 years. Few have engaged with his fictional and cinematic output. Those that do, such as Coderre (2014) and Hockx (2015), demonstrate how attention to media beyond his blog posts reveals further nuances in the relationship between rebellion and the cultural market, and the ways that Han Han himself negotiates between these positions. Han Han's films and public appearances bring to vivid life a series of other tropes in the broader cultural landscape, such as the interplay between global and local experiences, ambivalent responses to market reform, and, of course, gender. ${ }^{13}$

Whether they focus on his essays or his fiction, no previous study has considered masculinity in Han Han's work. ${ }^{14}$ As I intend to show in the remainder of this article, the representation and performance of masculinity in the Han Han phenomenon intertwines with his role as artist and entrepreneur in crucial ways, and cuts across his image as mainstream celebrity and as rebel. As well as pointing to a residual conservatism in his writing and actions, Han Han's masculinity leads to, or even relies upon, a silencing of female voices. The oppositional space that he appears to occupy outside of the system is therefore reserved for men alone.

\section{"Hen MAN": Han Han, consumer culture and the road}

The picture of Han Han as an adventurous outlaw wedded to the road has been repeated across several other advertising campaigns. In the mid2000s, the Japanese car company Subaru began a series of adverts featuring Han Han, who is also a member of their rally car team; in one poster his face appears alongside the car, accompanied by the slogan "I go my own way" (Wo xing wo lu 我行我路). This image is a permanent banner above Han Han's own blog. The car used in his second film, Duckweed (Chengfeng polang 乘風破浪) (2017), is also a Subaru. The campaign is therefore an example of the porous boundaries between consumer product, Han Han's racing career, and his works. ${ }^{15}$ In 2010, a video for Chinese clothing company Vand featured Han Han walking alone down a road, wearing a backpack, as his voiceover declared, somewhat ironically, "I'm nobody's spokesperson" (Bu shi shei de daiyan 不是誰的代言). ${ }^{16}$ Volkswagen Polo continued to draw upon Han Han's association with the road and his reputation as maverick creative in a short film made in 2014, which concluded with Han Han striding down an empty road stretching out into the distance, to the slogan "Create your own significance" (Chuangzao ni de yiyi 創造你的意義). In 2013, the outdoor clothing company Camel produced a series of posters of Han Han in various rugged outdoor locations, from a tropical forest with a snake dangling menacingly in the background, to a snowy mountain range, icicles clinging to his beard. These are accompanied by Camel's slogan of "Take on the world" (Dantiao shijie 單挑世界); reports on this campaign observed that Han Han was looking "very manly" (hen MAN 很MAN). ${ }^{17}$

Again, beyond indicating the sustained tie between Han Han and consumer culture, these campaigns tell us much about the enduring appeal - and the lucrative potential - of an adventurous, mobile masculinity. In consistently framing Han Han as rugged outlaw, these brands tap into Western, now global, symbols of counterculture and individualist adventure: the rugged lone wanderer, the Indiana Jones-type explorer, the leather- clad rebel without a cause. The image of Han Han that appears here has become a vital part of his public persona and, as I will suggest, is woven into the fabric of his work. The integration between brand and work appears not just through blog banners and product placement, but through a more generalised spirit that infuses each advert and Han Han's own cultural production. The synergy that is created encourages us to read his work and his public appearances, including his performance and representations of masculinity, in an intertextual way. ${ }^{18}$

The narrative of the journey has not been plucked out of thin air, for aside from Han Han's career as a racer, a countercultural wanderlust runs through virtually all of his writing and film. He has written several essays about his experiences on the racing circuit, offering a lively insight into that world. In 2013 he published a volume of essays based on his driving experience, collected under the title Drifting Here and There (liu zheme piaolai piaoqu 就 這麼飄來飄去)..$^{19}$ At least half of the volume is taken up with photographs of Han Han. Showing him taking a sharp corner on a motorbike, celebrating on the winner's podium at the race track, striking a heroic pose on the roof of his car and more, they continue to make the case for Han Han as a freewheeling individual with a hint of machismo. Nods to the road continue in the title of his 2002 novel Like A Speeding Youth (Xiang shaonian la feichi 像少年啦飛馳) and his 2010 collection of essays, Setting Out (Chufa 出發); the Taiwanese edition for this latter collection included an English-language title on the book jacket: On the Road (Han 2010-1).

In his fiction, Han Han repeatedly makes a direct connection between the road and a macho masculinity. This is most clear in His Country (Ta de guo 他的國) (2009) and 1988: I Want to Talk with the World (1988: Wo xiang he zhege shijie tantan 1988: 我想和這個世界談談) (2010-2). The former features Zuo Xiaolong 左小龍, a young man who dreams of driving the circumference of China, and sees his motorbike as "an extension of his masculine strength" (Han 2009: 2). ${ }^{20}$ Zuo's motorbike, we are told, is "like his woman - he didn't like the idea of anyone else riding it," thus swiftly making apparent the possible links between macho road discourse and the

13. This is contrary to Wasserstrom's statement that, for China-watchers, it is only Han Han's essays that "matter." Jeffrey Wasserstrom, "Make Way for Han Han," Words without Borders, 15 November 2012, https://www.wordswithoutborders.org/dispatches/article/make-way-for-hanhan (accessed on $1^{\text {st }}$ November 2019). Cited in Hockx 2015

14. Few studies have considered gender in Han Han's work overall. For an exception, see jiang 2017, who provides an analysis of female marginalisation in Duckweed. Beyond academia, Han Han's attitude towards women has begun to attract attention. For example, see Xie Bingqiang 謝秉 強 “除了周國平還有那些震驚國人的“直男癌'言論” (Chule Zhou Guoping, haiyou na xie zhenjing guoren de 'zhinan'ai' yanlun, Apart from Zhou Guoping, what other 'straight male cancer' arguments have stunned the nation?), Pengpai xinwen, 14 January 2015, http://www. thepaper.cn/newsDetail_forward_1294158 (accessed on 21 May 2019).

A summary of the latest controversy to surround Han Han is provided in Pamela Hunt, "Why Are China's 'Real Men' All Second-Rate Stereotypes?," Sixth Tone, 23 October 2017, https://www. sixthtone.com/news/1001037/why-are-chinas-men-all-second-rate-stereotypes\%3F (accessed on 21 May 2019).

15. For his detractors, it is an example of why Han Han will never be a serious social critic. See Lydia Liu's comments in Evan Osnos, "The Han Dynasty," The New Yorker, 27 June 2011, https://www. newyorker.com/magazine/2011/07/04/the-han-dynasty (accessed 21 May 2019).

16. “韓寒'我是凡客”PS視頻火熱出爐” (Han Han “Wo shi fanke” PS shipin huore chulu, Han Han "I am Vancl" Brand New Video), TheChinaToday, 2 November 2010, https://www.youtube.com/ watch?v=FMmxiDuMYHM (accessed on 21 May 2019). The Vancl campaign also included posters of $\mathrm{Han} \mathrm{Han}$, which went viral online and prompted a series of memes.

17. “韓寒與駱駝非凡戶外世界” (Han Han yu Luotuo: feifan huwai shijie, Han Han and Camel: Special outdoor world), Xinlang caijing, 15 January 2013, http://finance.sina.com.cn/ roll/20130115/092514288961.shtml (accessed on 21 May 2019).

18. The idea of reading famous figures intertextually chimes with celebrity studies outside of China. See Moran (2000), DeCordova (1999), and Boyle (2010).

19. Many of these essays are collected in Han (2016).

20. To complete the picture of rugged machismo clinging to phallic objects, this is followed by the observation that "if the ban on guns were lifted, he'd have got one of those, because they too were an extension of power" (2009: 2). 
objectification of women (4). 1988 follows the road trip of Lu Ziye 陸子野.21 His own surname a homophone for road (路), Lu is infected with a restless desire to drive "far from here" (Han 2010-2: 188). The narrative is filled with lines such as "I dreamed of taking a trip in a fast car with a beautiful woman beside me, speeding off into the distance" (ibid. 116), and the observation that "You've got to visit a brothel if you want to really know a city. For a man, that's the quickest and best way of getting to know a place" (ibid. 220). Mirroring Han Han's other engagements with the road, the novel therefore recalls - at least initially - a Dean Moriarty-esque, macho mobility.

The Han Han phenomenon is therefore laced with a celebration of the road as a site of nonconformity and adventure. The formula appears through the plotlines of his novels but is also supported through slogans, visual hints, and homages dotted through corporate sponsorship and his own marketing. Much of the iconography appears a deliberate tribute to American cultural traditions, an indicator of the cultural flows that continue alongside globalisation. It would be a mistake, however, to read the phenomenon merely as a declaration of some form of cosmopolitanism, or simply aping Western values and role models. The celebration of the road as a site of excitement and self-discovery also chimes with changing experiences of travel within China, as well as with longstanding local archetypes of mobile men.

\section{Chinese journeys}

Han Han's personal experience and interests only partially explain the appeal of road discourse for Han Han and the Chinese public. It has become commonplace to observe that over the past four decades China has become a country of migrant workers, business travellers, overseas students, and tourists; it is a nation that travels. Much of this movement is increasingly undertaken by car. As Coderre argues, Han Han's link to the road is partly a reflection of the shift towards automobility that China has undergone since the 1990s (Coderre 2014: 16). ${ }^{22}$ The country has undertaken a monumental highway-building project, creating a network that aims to link the largest cities across the country. Standing at $11,605 \mathrm{~km}$ in 2000, by 2014 the network measured 104,438 km, having overtaken the United States in $2012 .^{23}$ Private car ownership, virtually unheard of before the 1980s, has increased from 820,000 registered in 1990 to 35.34 million in 2007 (Coderre 2014: 16). For those social classes that can afford it, travel for leisure has increased phenomenally, implicated with discourses of modernity and an exploration of concepts of freedom and personal development (Nyíri 2006). The flipside of the discursive coin to migrant workers dogged by the derogatory label of mangliu (盲流, blind drifting), the concept of travel "off the beaten track" has become a way of finding adventure and discovering oneself, creating a collection of seductive and somewhat amorphous ideas that Han Han's campaigns tap into (Vasantkumar 2014; Chen and Weiler 2014).

Before these vast changes in infrastructure, and a growing appetite for "modern" autonomous travel, the journey has long been a significant trope in Chinese cultural production (Lee 1985; Cai 2004: 127-54; Hunt 2016). Depictions of travel are an effective means of surveying the nation in the contemporary age, exploring China's historical change, its developing economic might, and its engagement with other parts of the globe..$^{24}$ Automobility is a particularly evocative mode of transport in a time of rapidly growing consumer power and fast-paced moral shifts that have prompted pressing questions about freedom and autonomy (Featherstone, Urry, and Thrift 2005).
At this juncture, we might remind ourselves that mobilities studies scholars have demonstrated the gendered nature of travel and travel discourse throughout history, including road movies and road novels (Cresswell and Uteng 2012). Susan Hanson summarises this as a dualism that "equates women and femininity with the home, the private, with domestic spaces and restricted movement." Meanwhile, men are equated with "the not-home, the public... and expansive movement" that brings "excitement, challenges, new experiences, encounters with the unknown" (2010: 9).

Equally, as has been well documented, within China travel has also historically been associated with masculinity, part of the outer wai (外) that was reserved for men while women were either literally or discursively consigned to the inner nei (內). Within this framework, travel is not only reserved for men, but is a means of strengthening masculinity, as was the case for male literati sojourners, whose travel allowed them to establish homosocial bonds (Mann 2000; Huang 2007).

In the depiction of Han Han as manly and mobile, then, we are not just subject to echoes of Western-inspired cowboys but also more locallysourced male sojourners. Framed as a writer-turned-wanderer, he appears as a postsocialist member of the travelling literati, perhaps. More obvious are the references to the youxia 遊俠 or knight-errant, or the haohan 好 漢 or "good fellow." Emerging as an archetype of manliness in the popular culture of the Ming dynasty, most famously in Water Margin (Shuihu zhuan 水滸傳), haohan were physically strong and emotionally restrained, prizing homosocial bonds above all else (Jenner 1993; Boretz 2010). Youxia are also associated with male friendship, honour, and loyalty (Vitiello 2000; Zheng 2015). Crucially, such cultural ideals are closely associated with movement and marginality and especially the jianghu 江湖, the world on the margins populated by roving outcasts and outlaws. In turning their back on the mainstream and prioritising homosocial relationships to those with the state, residents of the jianghu carry with them the hint (or more) of subversion. Masculinities in the Han Han phenomenon are therefore another example of how the cultural field in the postsocialist era is marked by hybridity and simultaneous "discontinuity and continuity" (Zhang 2008: 10). The roving men that appear in the Han Han phenomenon are assembled out of a range of global and local cultural resources as well as Han Han's personal experiences of the road. They reflect the way that globalisation and global cultural flows help create a set of coordinates for "doing man," but also, and crucially, they demonstrate the tenacity of local masculine ideals.

The next section will consider the link between mobility and masculinity in more detail through a discussion of The Continent, which picks up the discourse of the road again. Once the narrative is under Han Han's more direct control, journeys and mobile masculinity are presented as rather more complex subjects than we see in his advertising campaigns. However, the resulting depictions of travel and of masculinity are remarkably similar to the images we have seen celebrated in the advertisements. As above, mobile men are developed out of global and local cultural archetypes; and these

21. See Coderre (2014) for a thorough analysis of the novel in terms of the road novel genre.

22. Seiler defines automobility as "the interlocking set of economic, social, philosophical, legal, political and aesthetic structures and psychological dispositions that facilitates automobile use on a grand scale" (Seiler 2012: 358).

23. 國家統計局 (Guojia tongjiju, National Bureau of Statistics), www.stats.gov.cn/tjsj/ndsj/ (accessed on 21 May 2019). See also Bosker, Deichmann, and Roberts (2018).

24. See also the metaphors of mobility that Chinese leaders have employed as they steer the country through reform, including more recently Xi Jinping's call at Davos 2017 for nations to join China in the "economic train of success," or his 2019 declaration that China was facing a "new Long March." 
depictions cut across, and complicate, the overlaid messages of adventure and rebellion.

\section{The Continent}

Han Han's directing and screenwriting debut earned over 100 million USD at the box office and mixed reviews (Cai 2017). ${ }^{25}$ Just as Han Han's writing reveals an ambivalent assessment of the results of postsocialist market reform, rejecting any suggestion of idealism, he approaches the trope of the journey here with ambivalence, both celebrating the open road and deflating the heroic ideals that might be associated with it. This approach, in fact, aligns itself with that of the road movie genre, a culturally ambiguous event shot through with "forlorn uncertainty" even as it celebrates the joy of movement (Laderman 2002: 19, 50). As we will see, The Continent keeps to many other tropes associated with the road movie genre, including the journey as revealing the state of the nation and the self. The film also recreates the road movie's ambiguous relationship with consumerism and the market, resulting in narratives that are part rebellion and part conservatism. Moreover, in building on a link between the road and manliness, Han Han follows the tendency for the road movie genre "to presuppose a focus on masculinity" (ibid.: 21).

The story follows the journey of three men: Hu Sheng 胡生, Ma Haohan 馬浩漢, and jiang He 江河. These close friends live on an island at the easternmost point of the country, in a depressed hometown that is about to be demolished. When Jiang $\mathrm{He}$, a teacher and an aspiring novelist, is relocated to a school in the westernmost part of China, the three of them decide to take a road trip to drop him off. The car they drive provides us with another indication of the permeable boundary between Han Han's artistic work and his commercial responsibilities: it is a Volkswagen Polo Cross, its logo prominent throughout the film. ${ }^{26}$ The journey across the length of the country prompts a critical view of the nation, which appears to be filled with gangsters and con artists, grimy motels and pool halls. The individuals they meet along the way are largely cynical and lonely, battered by the maelstrom of market reform.

The three men are highly flawed, even buffoonish, and at first sight they appear to epitomise Chinese masculinity in crisis. Hu Sheng is known as the village idiot, so slow that he is accidentally left behind. Ma Haohan is an impetuous, pompous figure, given to grandiloquent speeches and ambitious plans that are swiftly deflated into nothing. Jiang $\mathrm{He}$ is a quiet man whose naïve belief in the goodness of others brings disaster on the travellers several times throughout their journey. Their trip is a series of misturns, failed hook-ups, breakdowns, and thefts, and ends with a particularly hurtful argument that causes $\mathrm{Ma}$ and jiang to part ways. It is therefore reasonable that commentators have presented the film as a pessimistic portrait of contemporary China (Cai 2017).

However, the cynicism and disillusionment that run through this film are belied by the way that the journey itself is shown on screen. The Volkswagen glides through a variety of visually stunning landscapes across the Zhoushan islands, Shanghai, Inner Mongolia, and Sichuan. As the camera lovingly pans over the car's body, and as we watch it send piles of autumnal leaves swirling into the air, speed across a bridge over a spectacular gorge, or hug the corners of a road winding through a pine forest, it as if we are viewing a rhapsody on (or commercial for?) the aesthetics of the automobile and the open road. More than a celebration of the beauty of natural landscape (or an extended sales pitch for the Volkswagen), the montages become a somewhat unexpected showcase of the Chinese Communist Party's (CCP) vast highway projects and engineering prowess. The film therefore provides further support for Coderre's suggestion that Han Han's celebration of automobility, no matter how critical in intent, is nonetheless "playing into the hands of a crucial part of the postsocialist market economy" (Coderre 2014: 19).

Moreover, the journey prompts a process of introspection and selfdiscovery that ultimately leads to a form of redemption, particularly in the case of Jiang He. At the film's conclusion, he returns to his hometown. He has published a novel based on their road trip, later adapted into a television series. It has become so successful that the town has finally become a thriving tourism centre, prompting a renaissance on the island and saving their hometown from destruction. It is telling that Jiang's achievements are established through overwhelming commercial profit as well as literary prowess, reflecting Han Han's own career path and seeming to reinforce a major message of the postsocialist literary field (Kong 2005): that success is measured in money made. ${ }^{27}$ In such a way, mobility initially brings about unsteadiness and anxiety, prompting a critical survey of the nation and the masculine self, but ends in resolution through artistic achievement and wealth.

It is clear that the resolution and reward that the road brings are only available to men. Throughout the film, the journey is tightly linked to masculinity. As is the case with his novels, and, following a trope that runs through Chinese discursive tradition and road movies, travel in the film is essentially a male pursuit. Women act either as objects to be visited and moved on from, such as Zhou Mo 週沫 and Liu Yingying 劉鶯鶯, or as docile passengers, as is the case with Su Mi 蘇米, whom Jiang tries (and initially fails) to rescue from a gang leader. Su Mi's line, coolly delivered to Jiang, says it all: "I would tell you all my stories if I had the opportunity. Unfortunately, I have none." There is simply no space for women's stories in this film, or for their character development. Thus, for all Han Han's iconoclastic reputation, the film ultimately reinforces the familiar, restrictive idea of masculinity as equated with action and travel, and femininity with domestic passivity.

Equally, while the narrative initially appears to show male friendships breaking down, several moments reinforce, rather than deflate, the romance of homosocial ties. These are presented to us in a set of scenes of male bonding recognisable to anyone familiar with the buddy or road movie genre: the friends sit in comradely (and manly) silence, for example, as they gaze out over the ocean; they share their most secret dreams and thoughts by an open campfire in the western deserts; they relieve themselves together by the side of the road in what we might think of as an act of homosocial urination. This last is a particularly clear example of the ways in which global iconography of renegade, travelling masculinity have circulated into Chinese cinema, paralleling as it does a famous scene in Easy Rider (1969), in which three men also line up along the side of the road, and pee into a similarly lovely, lonely landscape. A visual echo such as this reminds us that, as we saw in the earlier advertising campaigns, The Continent is drawing on what is now a globally ingrained sense of countercultural, mobile masculinity. ${ }^{28}$

25. See Cai 2017 and Chen 2015 for more positive appraisals. For a more negative take, see Clarence Tsui, "'The Continent' ('Hou Hui Wu Qi'): film review," Hollywood Reporter, 28 July 2014, www. hollywoodreporter.com/review/continent-hou-hui-wu-Qi-721872 (accessed on 21 May 2019).

26. An advertising campaign for the car at the time included the title of the film and images of the starring actors.

27. The implicit rejection of the superiority of a mythical "pure" literature untainted by the market mirrors Han Han's famous online spat with Bai Ye in 2006, discussed in detail by Fumian 2009.

28. There are numerous other examples of non-Chinese pop culture in the film, for example the soundtrack, which features several international hits, including Skeeter Davis's "The End of the World" and Doris Day's "Que Sera Sera." The film opens to "Dongji Island's Song" (Dongji dao de ge 東極島的歌), a rewriting of "On Kazakhstan," the fictitious national anthem in Sacha Baron Cohen's 2006 film Borat. 
At the same time, the journey also contains clear nods to a more local understanding of the link between mobility and masculinity. The name Haohan, for example, is an obvious near-homonym for the roving haohan. Continuing this theme, Jiang He's name is close in sound and semantics to jianghu; the point is pressed home when Zhou Mo calls him "Jiang $\mathrm{Hu}^{\text {" in }}$ error. Jiang also calls to mind another archetype of Chinese masculinity: the caizi 才子, or talented scholar. This figure, who rose to prominence between the Yuan and Qing dynasties, continues today as an attractive male role model (Louie 2002; Song 2004; Hird 2017). Imbued as he was with wen qualities, the caizi had immense literary talent, something that jiang proves in producing a phenomenally successful novel. The caizi was depicted as handsome but delicate (often described as "fragile" or even "effeminate"), tallying with Jiang's sensitive air, bookish glasses, and soft voice. Finally, and crucially, the caizi held great sexual appeal that sprang from his literary prowess (Louie 2002; Song 2004). It is significant, therefore, that in the final frames of The Continent, Jiang returns home as a successful author with a woman - Su Mi. In the traditional formula of the caizi, his wen or literary talent has resulted in female adoration and material success.

jiang therefore appears initially as an example of marginalised masculinity (Connell 2005): a man who lacks power and authority as a result of his lower socioeconomic position (and his ambivalent responses to market reform and its consequences). In an attempt to compensate for this, he engages in behaviour associated with hegemonic masculinity; here, he combines the roving, marginalised working-class figure of the haohan with the more elite, literary caizi. Jiang He therefore appears as a synthesis of both wen and wu, the ultimate in successful masculinity (Louie 2002: 15).

Despite his identity as a man set apart from the centre, Jiang therefore still manages to benefit from "the patriarchal dividend," which is "the advantage men in general gain from the overall subordination of women" (Connell 2005: 79). The narrative echoes what Xueping Zhong (2000) identified in 1980s fiction: the "besieged" male, who is filled with anxiety over his perceived marginalisation in society and China's national and cultural weakness. In response, he displays a strong desire to discover a heteronormative, patriarchal male identity. Similarly, although The Continent appears at first to delve into flaws of contemporary Chinese men, Han Han is careful to demonstrate that Jiang is still able to conform to the kind of masculinity that is granted voice and authority. It is in the relative fates of Jiang $\mathrm{He}$ and Su Mi, then, that the wider implications of representing mobile masculinities in the Han Han phenomenon become clearest. If marginal men like jiang compensate for their marginality through adherence to longstanding conservative performances of masculinity, then these performances depend on, and replicate, ideals of femininity as docile and silent. Su Mi, already missing out on the adventure and redemption that has come with the journey, becomes little more than a body upon which Jiang finally establishes his ideal manliness.

Devin Orgeron (2009) argues that road movies are in fact an expression of a yearning for stability, and a desire to return home. There are homecomings in abundance in The Continent: in a literal sense, as Hu Sheng and jiang $\mathrm{He}$ return to their island; and, more importantly, in the sense of a return to an ideal masculinity, one that was sadly lacking at the beginning. The road is therefore not just a masculine space, but one that helps (re)construct a true and dominant masculinity in the face of crisis. There is also a return in the sense that the mobile men in Han Han's film are visual echoes of his own written work and his carefully cultivated public image. The restless misfits in The Continent are spiritual brothers of Han Han's Lu Ziye in 1988 or Zuo Xiaolong from His Country, and exude the same freewheeling energy as Han
Han the rally car racer and essayist. They repeat the same mantras as the Vancl-clad, Subaru-driving Han Han and reveal the same secret: that one can find oneself and one's masculine self-worth on the road.

I return to the topic of Han Han's close involvement with other brands not to suggest that he is somehow inauthentic or less culturally significant. It is to highlight, firstly, that this mode of masculinity - mobile, adventurous, and supposedly counter-cultural - has a widespread and tenacious appeal. Within masculinities studies, scholars have called for paying renewed attention to "global masculinities" (Connell 1998). Within Chinese masculinities studies, there has been a flurry of recent scholarship considering the transnational Chinese man, although these have tended to focus on middle-class fathers and businessmen (Louie 2014; Song and Hird 2018). The performance of manhood that appears in the Han Han phenomenon, with its recollection of a globally-recognised, leather-clad adventurer, combined with echoes of youxia and haohan, demonstrates that other types of masculinity also have transnational appeal.

Han Han's association with other brands also illustrates that in considering Chinese celebrity it is increasingly difficult to isolate their works from their commercial presence. As others have argued, Han Han is a pertinent example of how consumption and the cultural market intertwine with cultural production. More than this, he also indicates how market forces contribute to the construction and our reception of ideals of masculinity as they move across the globe and across film, text, and advertising. If his preoccupation is with men who are mobile, the Han Han phenomenon also provides us with a compelling example of how an image of masculinity can move across different media, attached to the coattails of a highly mobile artist, circulating rapidly across devices and platforms.

\section{Conclusion}

Whether we consider his commercial presence or his creative work, the Han Han phenomenon repeatedly produces a celebratory picture of the mobile man who is a bold maverick, engaging in autonomous travel that leads to agency, creativity, and material reward.

The phenomenon therefore provides us with an opportunity to reflect on the multiple ways that mobility and masculinity link together in cultural imagination. First, and most obviously, in keeping with the conventions of road movies across the world, and with discursive traditions within China, the road tends to be reserved for men, and the making of men. Only men travel, and as they travel they discover their "true" masculinity. This leads, happily enough, to their reaping the patriarchal dividend and a spiritual return home. Secondly, masculinity is mobile in the sense of moving concepts of men: models and images of men travel to us across time and across space, be it from the ancient jianghu or late twentieth century America. Thirdly, the Han Han phenomenon provides us with an example of a masculinity that moves across different media, with a highly mobile artist, circulating from Internet banner to online video to big-screen cinema, and reinforcing itself as it does so. It is an irony, then, that the actual image of masculinity that he presents us with remains somewhat unchanging.

What, then, is the appeal of this mobile man for the Han Han phenomenon and postsocialist cultural production? It is in part a product of Han Han's idiosyncratic career path as writer and filmmaker meets racer, and the shifting experiences of travel and automobility in post-reform China. But the key to the image of maverick mobility is that, for all its outlaw trappings, it produces a form of masculinity that is at its heart deeply conformist. As they turn their backs on the mainstream, whether this means wandering the 
metaphorical jianghu or driving along lonely highways, both Han Han and his characters cling to hegemonic masculinity and the benefits it confers on those who can display it. The mobile men in the Han Han phenomenon find agency, fraternal bonding, creative achievement, and sexual adventure as they move, and they are therefore able to simultaneously occupy positions of rebel and of authoritative, "real" man.

A focus on Han Han provides valuable insights for masculinities studies; and a focus on masculinity adds a new angle to our conversations about the Han Han phenomenon and cultural production in postsocialist China. In the first instance, the phenomenon is an effective demonstration of two of the major strands of Chinese masculinities studies at work: in the call-backs to films such as Easy Rider, manhood appears as an example of "globalization [inflecting] the configurations of masculinities (...) with transnational dimensions" (Hird and Song 2018: 1). At the same time, references to longstanding archetypes such as the haohan and the caizi reveal the continuing influence of traditional modes of masculinity and that "inside the new clothing of Chinese man today, we can still find the historical Chinese man" (Louie 2016: 4). Moreover, Han Han and his notably coherent representation of masculinity serve as a reminder of the importance of considering consumer culture, celebrity, and branding opportunities. Commercial ties reinforce, help circulate, or even drive certain elements of Han Han's work, including his construction of gender.

In the second instance, by focusing on masculinity in the Han Han phenomenon, we are provided with a reminder - should we ever need one - of the "usefulness" of gender in the study of postsocialist China (Scott 1986; Hershatter and Zheng 2008). Discussions of Han Han tend to revolve around either his status as deviant genius (Yang 2013: log) or sell-out. A gendered lens contributes to this discussion by demonstrating that both his participation in the cultural market and his cultural rebellion are coloured by his construction of masculinity. The mobile, rebellious masculinity that
Han Han helps build is not significant simply because of what it tells us about men in postsocialist cultural production; it also demonstrates that the construction of masculinities such as these is a project in maintaining patriarchal hierarchies. The rebel outlier images that Han Han develops are inconsistent with the conservative masculinity that they eventually return to, revealing that his cultural rebellion is curtailed not only by his commercial interests but also by his gender performance. But beyond this, the mobile masculinities are built upon, and reinforce, representations of women as passive and voiceless objects. The Han Han phenomenon gives us stories of men who, as the song goes, "were not born to follow," but they lead us ultimately to conservative performances of masculinity and women's silence; for all Han Han's iconoclastic reputation, his narratives of movement involve a few steps back.

\section{Acknowledgements}

The author would like to thank the two anonymous reviewers for their helpful suggestions, and the organisers and attendees of the second conference of the China Academic Network on Gender for their comments on the first version of this paper. The author gratefully acknowledges the support of the Leverhulme Trust.

I Pamela Hunt is a Leverhulme Early Career Research Fellow at the University of Oxford, and Junior Research Fellow at Brasenose College, Oxford. Her research focuses on representations of masculinity and mobility in contemporary Chinese literature and film. Oxford China Centre, Dickson Poon Building, Canterbury Rd, Oxford OX2 6LU, United Kingdom (pamela.hunt@orinst.ox.ac.uk).

Manuscript received on 5 August 2019. Accepted on 19 June 2020.

\section{Primary Sources}

HAN, Han 韓寒. 2009. 他的國 (Ta de guo, His country). Shenyang: Wanjuan chubanshe.

HAN, Han 韓寒. 2010-1. 出發 (Chu fa, Setting out). Taipei: Xinjingdian wenhua.

HAN, Han 韓寒. 2010-2. 1988: 我想和這個世界談談 (1988: Wo xiang he zhege shijie tantan, 1988: I Want to Talk with the World). Taipei: Dakuai wenhua.

HAN, Han 韓寒. 2013. 就這麼飄來飄去 (Jiu zheme piaolai piaoqu, Drifting Here and There). Tianjin: Tianjin renmin chubanshe.
HAN, Han 韓寒. 2014. 後會無期 (Houhui wuqi, The Continent). Beijing: Laurel Films, Guomai Culture and Film, Bona Film Group, 2014. Youku.

HAN, Han. 2016. The Trouble with Me: And Other Essays about Making Trouble in China Today. New York: Simon \& Schuster.

HAN, Han 韓寒. 2017. 乘風破浪 (Chengfeng polang, Duckweed). Beijing: Shanghai Bona Culture and Media Company, Shanghai Tao Piao Piao Movie \& TV Culture Company. Youku.

HAN, Han 韓寒. 2019. 飛馳人生 (Feichi rensheng, Pegasus). Shanghai. Shanghai PMF Pictures. Youku. 


\section{References}

BARANOVITCH, Nimrod. 2003. China's New Voices: Popular Music, Ethnicity, Gender and Politics 1978-1997. Berkeley: University of California Press.

BARMÉ, Geremie. 1999. In the Red: On Contemporary Chinese Culture. New York: Columbia University Press.

BORETZ, Avron Albert. 2014. Gods, Ghosts and Gangsters: Ritual Violence, Martial Arts and Masculinity on the Margins of Chinese Society. Honolulu: University of Hawai'i Press.

BOSKER, Maarten, Uwe DEICHMANN, and Mark ROBERTS. 2018. "Hukou and Highways the Impact of China's Spatial Development Policies on Urbanization and Regional Inequality." Regional Science and Urban Economics 71: 91-109.

BOYLE, Ellexis. 2010. "The Intertextual Terminator: The Role of Film in Branding 'Arnold Schwarzenegger'." Journal of Communication Inquiry 34(1): 42-60.

CAI, Rong. 2004. The Subject in Crisis in Contemporary Chinese Literature. Honolulu: University of Hawai' i.

CAl, Shenshen. 2017. "Han Han and His Debut Film The Continent: Identity in Flux, Cruel Youth and Broken Ideals." In Shenshen Cai (ed.), Contemporary Chinese Films and Celebrity Directors. London: Palgrave Macmillan. 17-39.

CHEN, Hanyu, and Betty WEILER. 2014. "Chinese Donkey Friends in Tibet: Evidence from the Cyberspace Community." Journal of China Tourism Research 10(4): 475-92.

CHEN, Yue'e 陳月娥. 2015. “解讀電影“後會無期'的成功之路” (Jiedu dianying 'houhuiwuqi' de chenggong zhi lu, Analysing the road to success for The Continent). Hubei Hanshoudaxue xuebao. 28(1): 190-1.

CHEN, Xiaoming 陳曉明. 2009. 中國當代文學住潮 (Zhongguo dangdai wenxue zhuchao, Main Trends in Contemporary Chinese Literature). Beijing: Beijing daxue chubanshe.

CODERRE, Laurence. 2014. "Meaningful Mobility and the Ties that Bind: 1988 as a Postsocialist Road Story." Modern Chinese Literature and Culture 26(2): 1-37.

CONNELL, R.W. 1998. "Masculinities and Globalization." Men and Masculinities 1(1): 3-23.

CONNELL, R.W. 2005. $2^{\text {nd }}$ edition. Masculinities. Oakland: University of California Press.

CRESSWELL, Tim, and Tanu Priya UTENG (eds). 2012. Gendered Mobilities. Farnham: Ashgate Publishing.
DECORDOVA, Richard. 1999. Picture Personalities: The Emergence of the Star System in America. Urbana and Chicago: University of Illinois Press.

FEATHERSTONE, Mike, Nigel THRIFT, and John URRY. 2005. Automobilities. London: Sage Publications.

FUMIAN, Marco. 2009. "The Temple and the Market: Controversial Positions in the Literary Field with Chinese Characteristics." Modern Chinese Literature and Culture 21(2): 126-66.

HANSON, Susan. 2010. "Gender and Mobility: New Approaches for Informing Sustainability." Gender, Place \& Culture 17(1): 5-23.

HEARN, Jeff, Marina BLAGOJEVIC, and Katherine HARRISON. 2013. Rethinking Transnational Men: Beyond, Between and Within Nations. London: Routledge.

HERSHATTER, Gail, and Wang ZHENG. 2008. "Chinese History: A Useful Category of Gender Analysis." The American Historical Review,113(5): 1404-21.

HIRD, Derek. 2012. "The Paradox of Pluralisation." In Peter Aggleton, Paul Boyce, Henrietta L. Moore, and Richard Parker (eds.), Understanding Global Sexualities: New Frontiers. London: Routledge. 49-65.

HIRD, Derek. 2016. "Moral Masculinities: Ethical Self-fashionings of Chinese Men in London." Nan, Nü 18(1): 115-47.

HIRD, Derek. 2017. "In League with Gentlemen: Junzi Masculinity and the Chinese Nation in Cultural Nationalist Discourses." Asia Pacific Perspectives 15(1): 14-35.

HIRD, Derek, and Geng SONG. 2018. The Cosmopolitan Dream: Transnational Chinese Masculinities in a Clobal Age. Hong Kong: Hong Kong University Press.

HOCKX, Michel. 2015. Internet Literature in China. New York: Columbia University Press.

HUANG, Martin. 2007. "Male Friendship in China: An Introduction." Nan Nü 9(1): 2-33.

HUNT, Pamela. 2016. "Drifting Through the Capital: 'Floating' Migrants and Masculinity in Xu Zechen's Fiction." The Journal of the British Association for Chinese Studies 6: 1-34.

JENNER, W.F. 1998. "Tough Guys, Mateship and Honour: Another Chinese Tradition." East Asian History 12: 1-34.

JIANG, Na 墩娜. 2017. “韓寒電影“乘風破浪”: 性別化和邊緣化 的女性立場” (Han Han dianying 'Chengfengpolang': xingbiehua he bianyuanhua de nüxing lichang, Han Han's film Duckweed: gender stereotyping and the marginalisation of women). Lanzhou jiaoyuxueyuan xuebao 33(7): 48-9. 
KONG, Shuyu. 2005. Consuming Literature: Best Sellers and the Commercialization of Literary Production in Contemporary China. Stanford: Stanford University Press.

LADERMAN, David. 2002. Driving Visions: Exploring the Road Movie. Austin: University of Texas Press.

LEE, Leo Ou-Fan. 1985. "The Solitary Traveler: Images of the Self in Modern Chinese Literature." In Robert E. Hegel and Richard C. Hessney (eds.), Expressions of the Self in Chinese Literature. New York: Columbia University Press. 282-307.

LI, Xuan, and William JANKOWIAK. 2016. "The Chinese Father: Masculinity, Conjugal Love, and Parental Involvement." In Kam Louie (ed.), Changing Chinese Masculinities: From Imperial Pillars of State of Global Real Men. Hong Kong: Hong Kong University Press. 186-203.

LIU, Petrus, and Lisa ROFEL (eds.). 2018. Wolf Warrior II: The Rise of China and Gender/Sexual Politics. MCLC Resource Center Publication February. http://u.osu.edu/mclc/online-series/liu-rofel/ (accessed on 22 May 2019).

LOUIE, Kam. 2002. Theorising Chinese Masculinity: Society and Gender in China. Cambridge: Cambridge University Press.

LOUIE, Kam. 2015. Chinese Masculinities in a Globalizing World. London and New York: Routledge.

LOUIE, Kam (ed.). 2016. Changing Chinese Masculinities: From Imperial Pillars of State of Global Real Men. Hong Kong: Hong Kong University Press.

LUO, Xianrong, Songshuang HUANG, and Graham BROWN. 2015 "Backpacking in China: A Netnographic Analysis of Donky Friends' Travel Behaviour." Journal of China Tourism Research 11(1): 67-84.

LU, Sheldon. 2007. Chinese Modernity and Global Biopolitics. Honolulu: University of Hawai'i Press.

MANN, Susan. 2000. "The Male Bond in Chinese History and Culture." The American Historical Review 105(5): 1600-14.

MORAN, Joe. 2000. Star Authors: Literary Celebrity in America. London: Pluto Press.

NYIRI, Pàl. 2006. Scenic Spots: Chinese Tourism, the State and Cultural Authority. Seattle: University of Washington Press.

ORGERON, Devin. 2009. Road Movies: From Muybridge and Méliès to Lynch and Kiarostami. London: Palgrave Macmillan.

OSBURG, John. 2013. Anxious Wealth: Money and Morality Among China's New Rich. Stanford: Stanford University Press.

SCOTT, Joan W. 1986. "Gender: A Useful Category of Historical Analysis." The American Historical Review 91(5): 1053-75.
SEILER, Cotten. 2012. "Welcoming China to Modernity: US Fantasies of Chinese Automobility." Public Culture 24. https://doi. org/10.1215/08992363-1535534

SHI, Aidong 施愛東. 2013. “韓寒神話的史詩母題” (Han Han shenhua de shishi muti, The epic motif of the Han Han myth). Qinghua daxue xuebao 28(1): 5-29.

SONG, Geng. 2004. The Fragile Scholar: Power and Masculinity in Chinese Culture. Hong Kong: Hong Kong University Press.

SONG, Geng. 2010. "Chinese Masculinities Revisited: Male Images in Contemporary Chinese TV Drama Serials. Modern China 36(4): 404-34. https://doi.org/10.1177/0097700410368221.

STRAFELLA, Giorgio, and Daria BERG. 2015. "The Making of an Online Celebrity: A Critical Analysis of Han Han's Blog." China Information 29(3): 352-76.

SUN, Shu 孫曙. 2014. “韓寒論” (Han Han lun, On Han Han). Shantou daxue xuebao 1(5): 32-9.

VASANTKUMAR, Chris. 2014. "Dreamworld, Shambala, Gannan: The Shangrilazation of China's 'Little Tibet'." In Emily T. Yeh and Christopher R. Coggins (eds.), Mapping Shangrila: Contested Landscapes in the Sino-Tibetan Borderlands. Seattle and London: Washington University Press. 51-74.

VEG, Sebastian. 2019. Minjian: The Rise of China's Grassroots Intellectuals. New York: Columbia University Press.

WEN, Rui 文瑞, and BI Wenjun 畢文君. 2015. “新媒體視閾下的文學 期刊閲讀 - 以韓寒主編的新鋭文學期刊'ONE - 個'為個案” (Xin meiti shiyuxia de wenxueqikan yuedu - yi Han Han zhubian de xinrui wenxue qikan 'ONE yi ge' wei ge an, Reading literary journals in new media - taking the cutting edge literary journal "ONE," edited by Han Han, as a case study). Kaili xueyuan xuebao 33(5).

WHITEHEAD, Stephen. 2002. Men and Masculinities: Key Themes and New Directions. Cambridge: Polity Press.

YANG, Lijun. 2013. "Han Han and the Public." In Perry Link, Richard P. Madsen, and Paul G. Pickowicz (eds.), Restless China. Lanham: Rowman \& Littlefield. 109-28.

ZHANG, Xudong. 2008. Postsocialism and Cultural Politics: China in the Last Decade of the Twentieth Century. Durham: Duke University Press.

ZHONG, Xueping. 2000. Masculinities Besieged? Issues of Modernity and Male Subjectivity in Chinese Literature of the Late Twentieth Century. Durham and London: Duke. 